\title{
Role of Plant Traits in Photosynthesis and Thermal Damage Avoidance under Warmer and Drier Climates in Boreal Forests
}

\author{
Guiomar Ruiz-Pérez ${ }^{1, *(\mathbb{D})}$, Samuli Launiainen ${ }^{2} \mathbb{1}$ and Giulia Vico ${ }^{1}$ (D) \\ 1 Department of Crop Production Ecology, Swedish University of Agricultural Sciences (SLU), \\ Uppsala, 75007, Sweden; giulia.vico@slu.se \\ 2 Natural Resources Institute Finland (LUKE), Helsinki, 00790, Finland; samuli.launiainen@luke.fi \\ * Correspondence: guiomar.ruiz.perez@slu.se
}

Received: 14 March 2019; Accepted: 3 May 2019; Published: 8 May 2019

\begin{abstract}
In the future, boreal forests will face warmer and in some cases drier conditions, potentially resulting in extreme leaf temperatures and reduced photosynthesis. One potential and still partially unexplored avenue to prepare boreal forest for future climates is the identification of plant traits that may support photosynthetic rates under a changing climate. However, the interplay among plant traits, soil water depletion and the occurrence of heat stress has been seldom explored in boreal forests. Here, a mechanistic model describing energy and mass exchanges among the soil, plant and atmosphere is employed to identify which combinations of growing conditions and plant traits allow trees to simultaneously keep high photosynthetic rates and prevent thermal damage under current and future growing conditions. Our results show that the simultaneous lack of precipitation and warm temperatures is the main trigger of thermal damage and reduction of photosynthesis. Traits that facilitate the coupling of leaves to the atmosphere are key to avoid thermal damage and guarantee the maintenance of assimilation rates in the future. Nevertheless, the same set of traits may not maximize forest productivity over current growing conditions. As such, an effective trait selection needs to explicitly consider the expected changes in the growing conditions, both in terms of averages and extremes.
\end{abstract}

Keywords: boreal forest; leaf temperature; photosynthesis; water availability; leaf thermal damage; thermoregulation

\section{Introduction}

Plant growth and development involve numerous biochemical reactions that are sensitive to temperature [1]. At the leaf level, high temperatures may lead to a decrease in photosynthesis and an increase in respiration, thus reducing ovetrall net carbon dioxide $\left(\mathrm{CO}_{2}\right)$ assimilation rate [2]. Under extreme conditions, plant thermotolerance might be exceeded, leading to permanent damage to the photosynthetic machinery [3]. Leaf thermal damage occurs when leaf temperature $\left(\mathrm{T}_{\mathrm{L}}\right)$ exceeds a critical temperature ( $\left.\mathrm{T}_{\mathrm{CRIT}}\right)$, but the damage becomes permanent if $\mathrm{T}_{\mathrm{L}}$ exceeds an even higher thermal threshold, often termed 'maximum temperature' [3-7].

Leaf temperature is defined by the interplay between plant traits (chiefly, leaf size and shape [8], albedo [9] and stomatal conductance [10]) and environmental conditions (irradiance, air temperature and humidity, plant water availability). When plants are well-watered and the canopy is well-coupled with the surrounding atmosphere, air temperature $\left(\mathrm{T}_{\mathrm{A}}\right)$ and $\mathrm{T}_{\mathrm{L}}$ are generally well correlated, although thermal regulation can result in leaves being cooler than air in warm conditions and warmer 
otherwise [11]. Low wind speed and plant water shortage can lead to $\mathrm{T}_{\mathrm{L}}$ substantially exceeding $\mathrm{T}_{\mathrm{A}}$ [12-14], by reducing the leaf evaporative cooling.

Climate change projections suggest a global increase in the frequency of warm days and nights, heat waves and, in some locations, dry spells [15]. Boreal forests are warming up twice as fast as other ecosystems. As a result of higher temperatures and, in some regions, reduced summer precipitation [15], they will be subject to more frequent periods of low water availability. Warming, together with low water, is already negatively affecting forest productivity $[16,17]$ and threatening the survival of sensitive species [18]. This is especially problematic in the boreal region considering the role of boreal forests in the global carbon (C) cycle $[19,20]$ and as a biomass source in climate change mitigation policies [21]. However, while the joint effects of high air temperatures and low water availability and the occurrence of thermal damage and/or limitation of assimilation rates have been extensively studied in arid and semi-arid environments [22,23], the potential occurrence of such conditions has been mostly overlooked in more mesic environments and boreal forests [24]. To better understand the joint effects of high temperatures and low water availability is essential in order to identify the expected frequency of damaging conditions the potential extent of damage, and possible steps towards preparing boreal forests to future growing conditions.

One potential and still partially unexplored avenue for adaptation to climate change is the identification of combinations of plant traits that can support carbon uptake and reduce the risk of thermal damage in a changing climate [25]. In particular, the role of traits leading to high temperature tolerance has been little explored over boreal regions [26]. Similarly, the link between plant traits, water use and water stress has not been fully resolved in boreal forests [27]. Limited information and understanding may be partially due to the fact that measurements of comprehensive sets of traits and long-term monitoring of forest dynamics are expensive and time consuming, constraining the traits considered [27]. Mechanistic models offer a powerful tool to overcome these limitations, allowing the exploration of a wide set of traits and environmental conditions, including the expected warmer and drier conditions.

Here, a mechanistic model describing energy and mass exchanges among the soil, plant and atmosphere $[28,29]$ is applied to explore the role of plant traits and current and future environmental conditions on leaf temperature and net $\mathrm{CO}_{2}$ assimilation, with a focus on boreal forests. Specifically, we answer three questions, pertaining traits, growing conditions and their joint effects respectively: (i) Which are the dominant plant traits in regulating leaf temperature and $\mathrm{CO}_{2}$ assimilation? (ii) How do environmental conditions (e.g., air temperature and precipitation timing) interact in determining the occurrence of thermal damage and reduced $\mathrm{CO}_{2}$ assimilation? (iii) Which are the most suitable trait combinations for sustained $\mathrm{CO}_{2}$ assimilation and thermal damage avoidance? How do they differ between current and future, warmer and drier conditions? By answering these questions, this study identifies the key plant traits along the thermal safety $-\mathrm{C}$ fixation tradeoff, under current and future climates. It also suggests optimal trait combinations for thermal safety and productivity to cope with future climates. Therefore, this study contributes to disentangle the traits-growing conditions nexus, including the joint effect of increasing temperatures and more frequent lack of water in boreal forests.

\section{Materials and Methods}

\subsection{APES-Atmosphere-Plant Exchange Simulator Model}

We use the model APES (Atmosphere-Plant Exchange Simulator), previously developed, calibrated and validated in boreal forests. APES is a process-based one-dimensional multilayer, multi-species forest canopy-soil model, designed especially to account for the vertical structure and functional diversity. The model mechanistically solves the coupled energy, water and C cycles in the soil-vegetation-atmosphere system, using physical and physiological constraints. Only the modeling aspects most relevant for the purposes of this work, i.e., those related to the determination of leaf temperature and net $\mathrm{CO}_{2}$ assimilation rate, are briefly described here and in the Supplementary 
Materials. A complete description of this model and its validation, as well as some applications, can be found in Launiainen et al. [28,29].

In APES, the leaf temperature, $T_{L}$, is calculated separately for sunlit and shaded leaves within each canopy layer, by solving the coupled energy balance and net $\mathrm{CO}_{2}$ assimilation rate $\left(\mathrm{A}_{\text {net }}\right)$ (see the Supplementary Materials for the equations).

$\mathrm{A}_{\text {net }}$ is obtained based on the Farquhar model, as the minimum of Rubisco-limited and light-limited rate, which in turn depend on the maximum carboxylation rate $V_{C M A X}$ and the maximum electron transport rate $\mathrm{J}_{\mathrm{MAX}}$, respectively [30]. The temperature responses of both $\mathrm{V}_{\mathrm{CMAX}}$ and $\mathrm{J}_{\mathrm{MAX}}$ are as in Medlyn et al. [31]. Additionally, leaf respiration increases with $T_{L}$, so that $A_{n e t}$ reaches its maximum at an intermediate temperature (the optimal temperature for net $\mathrm{CO}_{2}$ assimilation). The parameters $\mathrm{V}_{\mathrm{CMAX}}, \mathrm{J}_{\mathrm{MAX}}$ and $\mathrm{R}_{\mathrm{d}}$ at reference temperature are affected by the leaf water potential $\left(\psi_{L}\right)$, following Kellomaki and Wang [32]. The stomatal conductance is computed by using the "unified stomatal model" proposed by Medlyn et al. [33].

The microclimatic gradients within the plant canopy are explicitly accounted for. The photosynthetic active (PAR) and near-infrared (NIR) radiation, and the long-wave balance are computed for each canopy layer as in Zhao and Qualls [34,35]. The profiles of air $\mathrm{CO}_{2}$ and $\mathrm{H}_{2} \mathrm{O}$ concentrations, $\mathrm{T}_{\mathrm{A}}$ and wind speed $(\mathrm{U})$ are computed using first-order turbulence closure schemes iteratively with solution of leaf energy and $\mathrm{CO}_{2}$ balance. The above-ground and soil processes are coupled through water and heat fluxes via feedbacks between soil and vegetation (rainfall interception, root water uptake, feedbacks to leaf physiological parameters).

\subsection{Metrics Evaluating Thermal Risk and Assimilation Capacity}

To explore the role of key plant traits and identify potential trade-offs between photosynthesis and thermoregulation, we focused on four metrics of thermal damage, tolerance and $\mathrm{CO}_{2}$ fixation.

\subsubsection{Maximum $\mathrm{T}_{\mathrm{L}}\left(\mathrm{T}_{\mathrm{L}, \max }\right)$}

$\mathrm{T}_{\mathrm{L}, \max }$ was determined as the maximum leaf temperature within the warmest three-day period during the growing season. For each time step $(30 \mathrm{~min})$, we first calculated the average of $\mathrm{T}_{\mathrm{L}}$ of each canopy layer in sunlit leaves, which are the ones most likely to experience the warmest temperatures. Using this average $T_{L}$ series, we then computed the three-day moving average. $T_{L, m a x}$ is the absolute maximum $\mathrm{T}_{\mathrm{L}}$ within the three-day window with the highest moving average. We selected a three-day period, as in O'Sullivan et al. [3], considering that plants can cope with high temperatures for short periods. Knowledge of $\mathrm{T}_{\mathrm{L}, \max }$ allows determining whether conditions may be conducive to thermal damage of the photosynthetic machinery, i.e., if the critical temperature $\left(\mathrm{T}_{\mathrm{CRIT}}\right)$ is exceeded over the growing season.

\subsubsection{Cumulated $A_{\text {net }}\left(A_{\text {net,cum }}\right)$}

$A_{\text {net,cum }}$ is the cumulated $A_{\text {net }}$ within the growing season. We first computed the average of $A_{n e t}$ at each time step $(30 \mathrm{~min})$, including both sunlit and shaded leaves, weighted by sunlit and shaded fractions of leaves at each layer and accounting for non-uniform leaf area distribution across

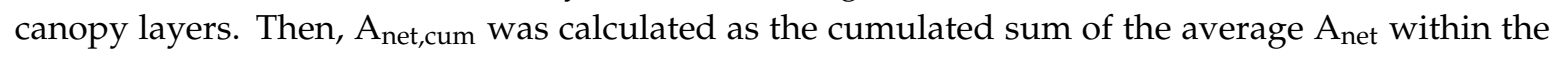
growing season.

\subsubsection{Maximum $A_{\text {net }}\left(A_{\text {net, } \max }\right)$}

The $A_{n e t, m a x}$ refers to the maximum average $A_{n e t}$ at each time step ( $30 \mathrm{~min}$ ) over the growing season, weighted by sunlit and shaded fractions of leaves at each layer and accounting for non-uniform leaf area distribution across canopy layers. 


\subsubsection{Thermal Range of High Photosynthesis $\left(\Delta \mathrm{T}_{90}\right)$}

The $\Delta \mathrm{T}_{90}$ is the extent of the temperature range where assimilation rates are $\geq 90 \%$ of their seasonal maximum value calculated above, $A_{\text {net,max }}$. Considering the previously computed $A_{n e t, m a x}$ and, at each time step, the average $A_{\text {net }}$ over the whole canopy, we identified the maximum and minimum $T_{L}$ for which $\mathrm{A}_{\text {net }}$ is equal to $90 \%$ of $\mathrm{A}_{\text {net,max }} . \Delta \mathrm{T}_{90}$ corresponds to the difference between those maximum and minimum $\mathrm{T}_{\mathrm{L}}$. We interpreted $\Delta \mathrm{T}_{90}$ as a proxy of leaf thermotolerance: broad $\Delta \mathrm{T}_{90}$ ranges mean that the $\mathrm{CO}_{2}$ assimilation rate is close to its maximum under a wide range of thermal conditions, while narrow $\Delta \mathrm{T}_{90}$ range necessarily implies a higher likelihood to experience sub-optimal thermal conditions for assimilation.

\subsection{Plant Traits Selection and Determination of Their Role}

\subsubsection{Selection of Plant Traits}

Only traits expected to have a direct most notable effect on leaf thermoregulation and C-fixation in APES were included in the analyses. Under set environmental conditions, $T_{L}$ is strongly affected by leaf size and shape [8], albedo [9] and traits related to stomatal conductance and hence regulation of transpiration [10]. These traits also affect the net $\mathrm{CO}_{2}$ assimilation rate, directly via its maximum rate, and indirectly, via the stomatal opening and the effects of temperature on leaf metabolic rates. Consequently, in the analyses below, we focused on the primary plant traits regulating the $\mathrm{CO}_{2}$ assimilation rate, the boundary layer and stomatal conductances ( $\mathrm{g}_{\mathrm{b}}$ and $\mathrm{g}_{\mathrm{s}}$, respectively), the absorption of solar radiation.

A total of six traits were selected: the maximum carboxylation rate at $25{ }^{\circ} \mathrm{C}, \mathrm{V}_{\mathrm{CMAX}, 25}$; the two parameters of the stomatal model, i.e., stomatal model slope in well-watered conditions $\mathrm{g}_{1}$ and a parameter describing the sensitivity of $g_{1}$ to soil water potential $\beta$ [33]; the effective leaf thickness, $1_{t}$, and PAR and NIR albedos, $\alpha_{\text {PAR }}$ and $\alpha_{\text {NIR }}$. This selection was based on the following considerations. Assuming leaves as flat plates, the effective leaf thickness, $1_{t}$, controls the boundary layer conductance $g_{b}[36,37]$. Conversely, the stomatal conductance, $g_{s}$, is mostly dependent on hydraulic and photosynthetic traits: in the stomatal model employed in APES [33], these aspects are summarized by the parameters $\mathrm{g}_{1}$ and $\beta$. Leaf temperature and photosynthesis also depend on the absorbed radiation, and hence on the leaf albedo for both photosynthetically active and near infrared radiation ( $\alpha_{\text {PAR }}$ and $\alpha_{\text {NIR }}$ respectively). Finally, according to the Farquhar model, the net $\mathrm{CO}_{2}$ assimilation rate depends on the maximum carboxylation rate, $\mathrm{V}_{\mathrm{CMAX}}$, the maximum electron transport rate, $\mathrm{J}_{\mathrm{MAX}}$, and the day respiration rates, $\mathrm{R}_{\mathrm{d}}$. These rates are functions of the corresponding rates at $25^{\circ} \mathrm{C}\left(\mathrm{V}_{\mathrm{CMAX}, 25}, \mathrm{~J}_{\mathrm{MAX}, 25}\right.$ and $\left.\mathrm{R}_{\mathrm{d}, 25}\right)$ and their response to temperature [31]. $\mathrm{J}_{\mathrm{MAX}, 25}$ and $\mathrm{R}_{\mathrm{d}, 25}$ are often well correlated with $\mathrm{V}_{\mathrm{CMAX}, 25}$, following Medlyn et al. [38] and Launiainen et al. [29], respectively, thus allowing to consider only $\mathrm{V}_{\mathrm{CMAX}, 25}$ as a key parameter of photosynthesis. Further details on trait selection and their role in leaf temperature regulation are given in the Supplementary Materials.

For each of these six traits, we considered realistic ranges, based on a literature search. These ranges were maintained intentionally broad, beyond those typical of current dominant coniferous and deciduous tree species in boreal forests (Table 1). Conversely, the understory and forest floor features were fixed in the model. Concretely, the understory consists of seedlings of Norway spruce, Silver birch and other deciduous species (LAI $\sim 0.5 \mathrm{~m}^{2} \mathrm{~m}^{-2}$ ), as specified in [29]. 
Table 1. Summary of the traits considered in the General Sensitivity Analysis (GSA), their ranges of variation emerging from the literature globally and for mid-to-high latitudes and corresponding supporting references.

\begin{tabular}{|c|c|c|c|c|}
\hline Trait & Range & Range for Mid-to-high Latitude & References & $\begin{array}{c}\text { References for } \\
\text { Mid-to-high Latitude }\end{array}$ \\
\hline $\begin{array}{c}\mathrm{V}_{\mathrm{CMAX}, 25} \\
\left(\mu \mathrm{mol} \mathrm{m}^{-2} \mathrm{~s}^{-1}\right)\end{array}$ & $20-120$ & $35-70$ & [39-42] & {$[29,39,40,43,44]$} \\
\hline $\begin{array}{l}1_{t} \\
(\mathrm{~m})\end{array}$ & $0.005-0.15$ & * & {$[11,45,46]$} & [29] \\
\hline $\begin{array}{c}\mathrm{g}_{1} \\
\left(\mathrm{kPa}^{0.5}\right)\end{array}$ & $1-15$ & $1.5-7$ & {$[33,38,47]$} & {$[29,33,38]$} \\
\hline $\begin{array}{l}\beta \\
(-)\end{array}$ & $0.05-3$ & $* *$ & {$[29,33,38]$} & {$[29,33,38]$} \\
\hline $\begin{array}{c}\alpha_{\text {PAR }} \\
(-)\end{array}$ & $0.02-0.3$ & $0.04-0.12$ & [48-50] & {$[29,48-50]$} \\
\hline$\alpha_{\mathrm{NIR}}$ & $0.1-0.7$ & $0.2-0.55$ & & \\
\hline
\end{tabular}

\subsubsection{General Sensitivity Analysis (GSA) and Determination of Dominant Traits}

A General Sensitivity Analysis (GSA) was run on APES to identify which of the focal traits are most important to maximize both instantaneous and cumulative $A_{\text {net }}$ and regulate $T_{L}$, reducing the risk of high temperature damage. To this aim, 100 trait sets were randomly generated from uniform distributions of each trait over the ranges specified in Table 1. The traits were sampled independently. The model was run using each trait set for current growing conditions (Section 2.4.1). The obtained simulated time series of $A_{n e t}$ and $T_{L}$ allowed the computation of the four metrics described in Section 2.2 for each trait set (maximum leaf temperature, $T_{\mathrm{L}, \max }$; the thermal range of high photosynthesis, $\Delta \mathrm{T}_{90}$, cumulated and maximum net assimilation, $\mathrm{A}_{\text {net,cum }}$ and $\mathrm{A}_{\text {net,max }}$ ).

The model results were then grouped based on whether the metrics exceeded pre-set thresholds. Specifically, a threshold was set for each metric in order to split the 100 trait sets into two groups: one containing the $\mathrm{m}$ trait sets for which metric is above the threshold (Group 1) and the others $n=(100-m)$ (Group 2). Then, for each trait, the cumulative probability distribution for the $m$ trait values in Group 1 and $n$ trait values in Group 2 were obtained. The higher the distance between the cumulative distribution functions, the more important the role of the trait value in defining the outcome. To measure the distance between the two empirical functions, the Kolmogorov-Smirnov (KS) two-sample test was used. This nonparametric method allows comparing two samples and quantifying the distance between the empirical distributions of the two samples [51]; thus, it can be used to rank the traits according to how dominant they are in determining the final outcome [52-54].

The thresholds for the grouping were selected to be the highest ones that allowed the greatest number of trait sets in the Group 1 while the number of dominant traits remained unchanged [53]. Indeed, choosing an excessively low threshold leads to (almost) no distinction between Group 1 and Group 2 so that the separation between the two distribution functions is negligible for all traits (i.e., no trait emerges as dominant). Conversely, choosing an excessively high threshold reduces substantially the number of trait sets for which the metric is above the threshold: in this case, Group 1 might not be representative except for a minority of trait sets, leading to a substantial separation between the two distribution functions for all traits (i.e., all traits are considered dominant). This approach was followed for each metric except $\mathrm{T}_{\mathrm{L}, \mathrm{max}}$. For the latter, we used $\mathrm{T}_{\mathrm{CRIT}}$-i.e., the temperature at which first symptoms of thermal damage appears. Following O'Sullivan et al. [3], based on the latitude of the reference study site (Section 2.4.1), $\mathrm{T}_{\mathrm{CRIT}}$ was set at $44.0^{\circ} \mathrm{C}$. This threshold also allowed a balanced partitioning of the 100 parameter sets into Group 1 and Group 2, i.e., the approach delineated above 
would have led to a similar value for the threshold. The resulting thresholds were: $\mathrm{T}_{\mathrm{L}, \max }=44.0^{\circ} \mathrm{C}$, $\mathrm{A}_{\text {net,cum }}=1,274 \mu \mathrm{mol} \mathrm{m}{ }^{-2}, \mathrm{~A}_{\text {net, } \max }=0.466 \mu \mathrm{mol} \mathrm{m} \mathrm{m}^{-2} \mathrm{~s}^{-1}$ and $\Delta \mathrm{T}_{90}=6.3^{\circ} \mathrm{C}$.

\subsubsection{Selection of Focal Trait Combinations}

Once the dominant traits were identified via Kolmogorov-Smirnov test, four sets of parameters were chosen to represent widely different outcomes in terms of thermotolerance and C fixation (Table 2). Given the focus on boreal forests, the focal trait combinations were chosen among those including trait values within the ranges typically observed in mid-to-high latitude forests (Table 1). We selected four trait combinations that showed contrasting thermal and productivity responses under identical growing conditions (2005 growing season). Specifically, trait combination 1 corresponds to the set of traits with the lowest performance (lowest $A_{\text {net,cum }}$ and $T_{L, M A X}$ exceeding $T_{C R I T}$ in 2005): it is representative of those trait combinations with low productivity and high risk of thermal damage, at least under the current conditions (Low Productivity-High Risk; hereafter, LP-HR). Combination 2 was instead the best performing combination, leading to high assimilation rates while preventing thermal damage, i.e., it is representative of individuals with high productivity and low risk of thermal damage (High Productivity-Low Risk; HP-LR). Combination 3 led to high assimilation rates but also to $\mathrm{T}_{\mathrm{L}, \mathrm{MAX}}$ on par with that of combination 1 , thus representing trait sets leading to high productivity but also high risk of thermal damage (High Productivity-High Risk; HP-HR). Finally, combination 4 resulted in assimilation rates similar to combination 1 but it did prevent the occurrence of thermal damage; thus, it corresponds to low productivity but also low risk of thermal damage (Low Productivity-Low Risk). These differences in assimilation and thermal metrics are the result of the following differences between the trait values. Combinations 1 (LP-HR) and 4 (LP-LR) have similar and low $\mathrm{V}_{\mathrm{CMAX}, 25}$; combinations 2 (HP-LR) and 3 (HP-HR) have a similar $\mathrm{V}_{\mathrm{CMAX}, 25}$, but these are higher than combinations 1 and 4 . Conversely, $l_{t}$ values in combinations 1 (LP-LR) and $3(\mathrm{HP}-\mathrm{HR})$ are similar and higher than the ones in combinations 2 (HP-LR) and 4 (LP-LR), the latter of which also have similar values. No patterns emerged relatively to the other traits, which were indeed not dominant as shown by the sensitivity analysis (see results in Section 3.1). These four combinations of traits together with their corresponding assimilation and thermal metrics are listed in Table 2.

Table 2. Combination of traits used to perform the climate scenarios analyses and the resulting values of the assimilation and thermal metrics for the growing season 2005. LP-HR: Low Productivity-High Risk of thermal damage; HP-LR: High Productivity-Low Risk of thermal damage; HP-HR: High Productivity-High Risk of thermal damage; LP-LR: Low Productivity-Low Risk of thermal damage.

\begin{tabular}{|c|c|c|c|c|c|c|c|c|c|c|}
\hline Trait Combination & 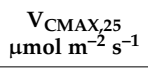 & $\begin{array}{l}\mathbf{l}_{\mathrm{t}} \\
\mathrm{m}\end{array}$ & $\begin{array}{c}\mathrm{g}_{1} \\
\mathbf{k P a}^{0.5}\end{array}$ & $\begin{array}{l}\beta \\
(-)\end{array}$ & $\underset{(-)}{\alpha_{\text {PAR }}}$ & $\underset{(-)}{\alpha_{N I R}}$ & $\begin{array}{c}\text { A }_{\text {net,cum }} \\
\mu \mathrm{mol} \mathrm{m^{-2 }}\end{array}$ & $\underset{{ }^{\circ} \mathbf{C}}{\mathrm{T}_{\mathrm{L}}}$ & 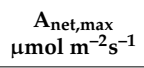 & $\begin{array}{c}\Delta \mathrm{T}_{90} \\
{ }^{\circ} \mathrm{C}\end{array}$ \\
\hline $\begin{array}{l}\text { Comb. } 1 \\
\text { (LP-HR) }\end{array}$ & 36.16 & 0.14 & 6.35 & 2.41 & 0.11 & 0.39 & 25235 & 49.50 & 8.15 & 6.02 \\
\hline $\begin{array}{l}\text { Comb. } 2 \\
\text { (HP-LR) }\end{array}$ & 57.36 & 0.02 & 2.19 & 0.70 & 0.27 & 0.60 & 32770 & 40.08 & 11.54 & 5.60 \\
\hline $\begin{array}{l}\text { Comb. } 3 \\
\text { (HP-HR) }\end{array}$ & 56.93 & 0.10 & 6.53 & 2.34 & 0.19 & 0.49 & 36818 & 46.18 & 12.58 & 5.83 \\
\hline $\begin{array}{l}\text { Comb. } 4 \\
\text { (LP-LR) }\end{array}$ & 36.37 & 0.03 & 6.18 & 1.92 & 0.22 & 0.52 & 25600 & 42.14 & 8.18 & 6.52 \\
\hline
\end{tabular}

\subsection{Growing Conditions}

The GSA was performed under current climatic conditions, corresponding to selected years in a study site in Finland (Section 2.4.1). Conversely, the focal combinations of traits were tested under both current and future warmer and/or drier growing conditions, as defined in Section 2.4.2. This approach allowed us to determine whether thermal damage and suboptimal photosynthetic rates would occur given certain temperature increase and intensity of the water stress, thus allowing the quantification of potential effects of climate change and the importance of trait selection in the future. 


\subsubsection{Current Growing Conditions}

Current growing conditions are based on meteorological data observed in the Hyytiälä field station SMEAR II (Station for Measuring Forest Ecosystem-Atmosphere Relations), located in Hyytiälä, Southern Finland $\left(61^{\circ} 51^{\prime} \mathrm{N}, 24^{\circ} 17^{\prime} \mathrm{E}\right)$. The annual mean temperature is $3^{\circ} \mathrm{C}$ and total mean annual precipitation is $700 \mathrm{~mm}$. All the meteorological data necessary for APES are routinely measured at this site. A complete description of the site and its measurements can be found in Kolari et al. [55]; Kulmala et al. [56] and Launiainen et al. [29].

The model was applied over selected growing seasons (2005 and 2006), here defined as the period of May 1st to September 30th [29], with the warmer period falling in the first half of July. The growing season 2005 can be considered as a normal one in the region, while 2006 was a dry year [57], slightly warmer than 2005. The two growing seasons were also characterized by a different precipitation timing: in 2005, the rainiest period occurred in late July and early August and the highest precipitation was recorded at the end of the growing season; in 2006, a dry spell occurred in late July and early August while two of the rainiest peaks were recorded in early July. Therefore, 2005 and 2006 present contrasting plant water availability, allowing us to analyze if these difference might lead to significant changes in thermoregulation and net $\mathrm{CO}_{2}$ assimilation.

\subsubsection{Scenarios of Future Growing Conditions}

Boreal regions are experiencing a rapid warming and an increase in the frequency and intensity of periods with low water availability as a consequence of changes in the timing and magnitude of precipitation, as well as increases in evapotranspiration from longer and warmer growing seasons [15]. Therefore, to generate climate change scenarios, we focused on air temperature $\left(\mathrm{T}_{\mathrm{A}}\right)$ and soil water potential $\left(\Psi_{S}\right)$.

The future scenarios were developed as follows. We considered two single days within the growing season of year 2005 as baseline: (i) the day where $T_{L}$ reached its maximum value (July 6th) and (ii) an average day with $\mathrm{T}_{\mathrm{A}}$ close to the median value for the growing season (May 20th). Then, we built scenarios of future growing conditions by shifting upwards the observed $\mathrm{T}_{\mathrm{A}}$ series of 1 to $10^{\circ} \mathrm{C}$ combined with decreasing soil water potential ranging from -0.5 to $-3 \mathrm{MPa}$. The soil water potential is considered constant within the day. For each scenario, we computed the instantaneous $A_{\text {net }}$ and $\mathrm{T}_{\mathrm{L}}$ at midday. While acknowledging their importance, other environmental variables such as wind speed and relative humidity were not modified. Thus, the vapor pressure deficit (VPD) was computed considering the new temperature values and the unchanged relative humidity.

Furthermore, we analyzed how trait combinations might affect soil water availability and how such changes may alter maximum and cumulated net $\mathrm{CO}_{2}$ assimilation. To this aim, the shift in $\mathrm{T}_{\mathrm{A}}$ series by 1 to $10^{\circ} \mathrm{C}$ was combined with imposing 5 to 30 day dry spells, with no precipitation. The dry spell was assumed to begin after the last precipitation event before the warmest period registered within the growing season of 2005 (i.e., June 27th). We then computed the corresponding $\Psi_{\mathrm{S}}$ at the end of the 5-30 day dry period, and the $\mathrm{A}_{\text {net,cum }}$ over the dry down.

In all cases, the length of the growing season was maintained unaltered, even though global warming may lead to longer growing seasons in boreal regions $[58,59]$. This simplifying assumption bears no consequence of the results discussed below, because the aim was to contrast different trait combinations under the same abiotic conditions.

\section{Results}

\subsection{Dominant Traits Emerging from the General Sensitivity Analysis (GSA)}

The General Sensitivity Analysis (GSA) allowed the identification of the traits most relevant for the four metrics: $T_{L, m a x}, A_{n e t, c u m}, A_{n e t, m a x}$ and $\Delta T_{90}$. The results are presented in Figure 1 and summarized next. 

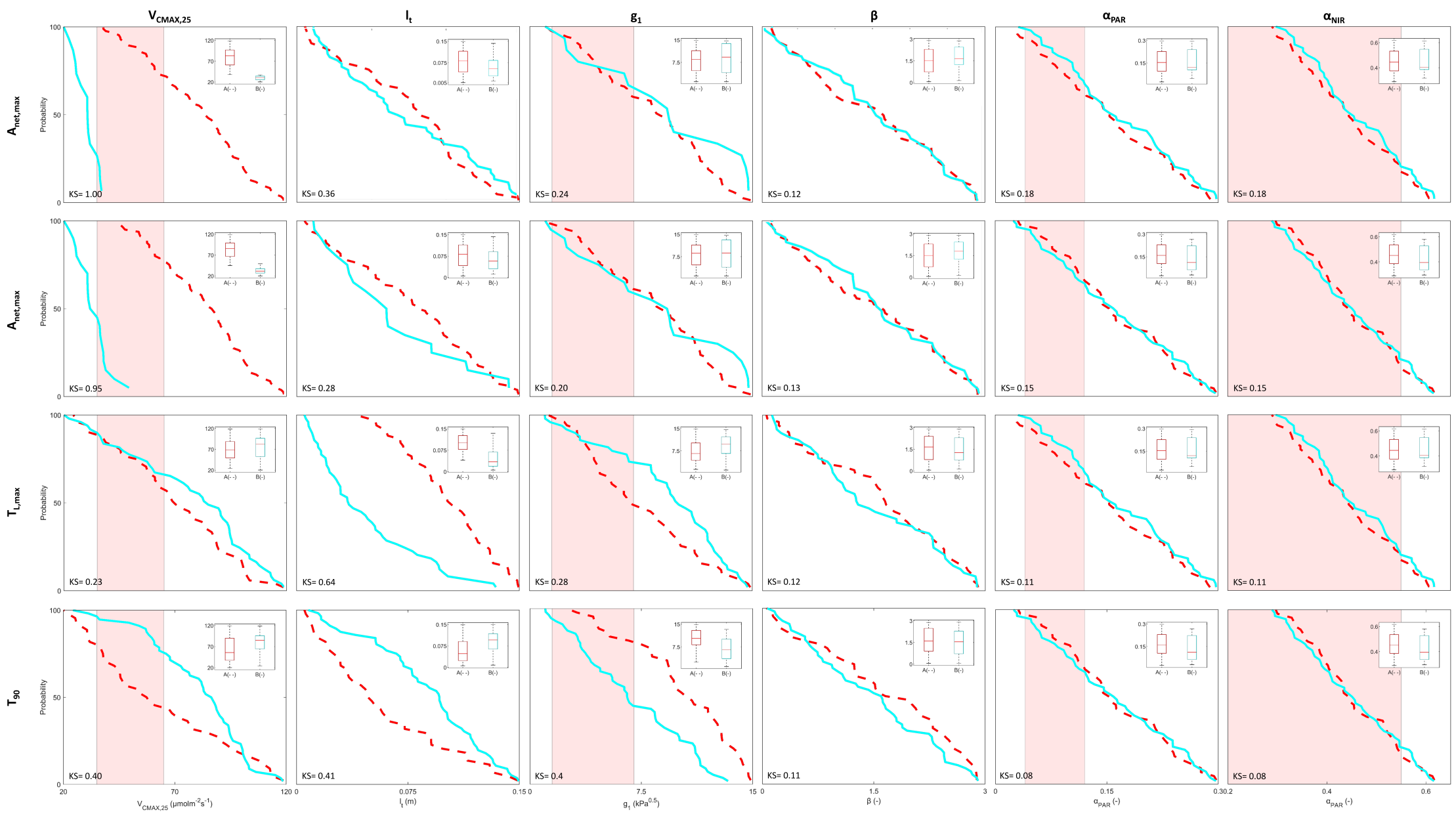

Figure 1. Results of the Global Sensitivity Analysis. Rows refer to the four metrics; columns to the six traits investigated. In each main plot, the lines are the empirical cumulative function of the trait values: blue solid lines refer to the trait values that lead to metric values below the metric-specific threshold; the red dashed lines refer to trait values that lead to metric values above the threshold. Shaded areas identify ranges of trait typically observed in mid-to-high latitudes. In the insets, the box and whisker plots compare and summarize the trait values leading to metric values above (left box; A-) and below (right box; B-) the threshold. The boxes extend from the first to the third quartile, the end of the whiskers are computed as $1.5 \times$ IQR (Interquantile Range). The median values are indicated by the horizontal red lines. 


\subsubsection{Maximum $\mathrm{T}_{\mathrm{L}}\left(\mathrm{T}_{\mathrm{L}, \max }\right)$}

Ranking the traits according to KS (Figure 1 ), the most dominant one was $l_{t}$, followed by $g_{1}$ and $\mathrm{V}_{\mathrm{CMAX}, 25}$. In the case of the leaf albedos $\left(\alpha_{\mathrm{PAR}}\right.$ and $\left.\alpha_{\mathrm{NIR}}\right)$ and $\beta$ values, the two distribution functions were overlapping and the KS value was negligible, i.e., the traits did not have a large effect on $\mathrm{T}_{\mathrm{L}, \max }$. The group containing the trait sets that did not result in thermal damage (i.e., $\mathrm{T}_{\mathrm{L}, \max }<\mathrm{T}_{\mathrm{CRIT}}$ ) had lower $\mathrm{l}_{\mathrm{t}}$, higher $\mathrm{g}_{1}$ and higher $\mathrm{V}_{\mathrm{CMAX}, 25}$. For values lower than $55 \mu \mathrm{mol} \mathrm{m} \mathrm{s}^{-2}$ (i.e., those typically observed in trees in mid-to-high latitudes; shaded range), the importance of $\mathrm{V}_{\mathrm{CMAX}, 25}$ decreases as evidenced by the two empirical distribution functions overlapping for such parameter values. The same behavior was shown by $\mathrm{g}_{1}$, the influence of which diminishes for values higher than $4 \mathrm{kPa}^{0.5}$.

\subsubsection{Cumulated $A_{\text {net }}\left(A_{\text {net,cum }}\right)$ and Maximum $A_{\text {net }}\left(A_{\text {net,max }}\right)$}

$A_{\text {net,cum }}$ was dominated by $\mathrm{V}_{\mathrm{CMAX}, 25}$, followed by $\mathrm{g}_{1}$ and $\mathrm{l}_{\mathrm{t}}$. Higher values of $\mathrm{V}_{\mathrm{CMAX}, 25}$ led to higher $A_{\text {net,cum }}$. Similarly, the group with higher $A_{\text {net,cum }}$ presented higher values of $g_{1}$ and $l_{t}$ up to values of $11 \mathrm{kPa}^{0.5}$ and $0.1 \mathrm{~m}$, respectively, above which the effect of these parameters on $A_{\text {net,cum }}$ shifted. Similar results were obtained regarding $A_{\text {net,max }}$ (Figure 1, third row).

\subsubsection{Thermal Range of High Photosynthesis $\left(\Delta \mathrm{T}_{90}\right)$}

$\Delta \mathrm{T}_{90}$ was equally dominated by $\mathrm{g}_{1}, \mathrm{l}_{\mathrm{t}}$ and $\mathrm{V}_{\mathrm{CMAX}, 25}$. The group with higher thermotolerance (i.e., broader $\Delta \mathrm{T}_{90}$ ) had higher $\mathrm{g}_{1}$ and lower $\mathrm{V}_{\mathrm{CMAX}, 25}$ and $\mathrm{l}_{\mathrm{t}}$ than the less thermotolerant one. Regarding the leaf albedos and $\beta$ values, the distribution functions were mainly overlapping and the KS value was almost negligible (Figure 1, bottom row). Note that, differently from the case of $\mathrm{T}_{\mathrm{L}, \max }, \mathrm{V}_{\mathrm{CMAX}, 25}$ is also dominant for parameter values typical of trees in mid-to-high latitudes.

\subsection{Role of the Growing Conditions}

\subsubsection{Differences between 2005 and 2006}

In both the 2005 and 2006 growing seasons, leaves did not reach their maximum temperature when $\mathrm{T}_{\mathrm{A}}$ was warmest, but rather after several consecutive days without precipitation (4 and 7 days in 2005 and 2006, respectively). No large differences between the days when the maximum $T_{L}$ are reached in each year were found in terms of radiation, wind speed and VPD.

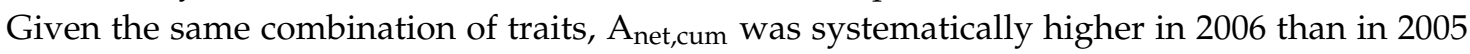
growing season (Figure 2, top), while $\mathrm{T}_{\mathrm{L}, \max }$ was systematically higher in 2005 than in 2006. Indeed, some combinations of traits led to thermal damage during 2005, while this threshold was not reached by any combination of traits during 2006. Conversely, no marked differences in terms of $A_{\text {net,max }}$ and $\Delta \mathrm{T}_{90}$ were found (Figure 2). 

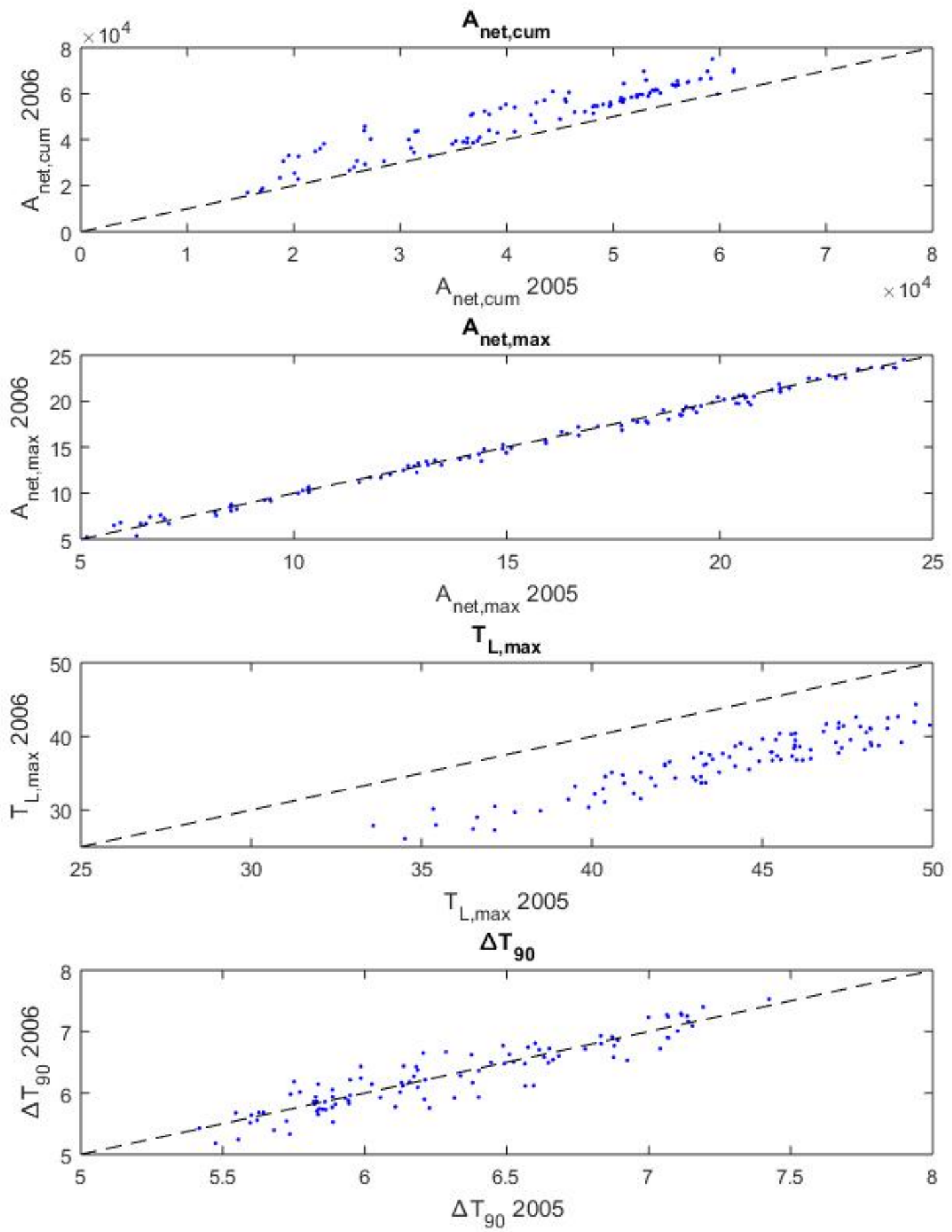

Figure 2. Comparison of model outputs for 2005 and 2006. Value of the four metrics $A_{\text {net,cum (in } \mu m o l}$ $\mathrm{m}^{-2}$ ), $\mathrm{A}_{\text {net,max }}$ (in $\mu \mathrm{mol} \mathrm{m} \mathrm{m}^{-2} \mathrm{~s}^{-1}$ ), $\mathrm{T}_{\mathrm{L}, \max }$ and $\Delta \mathrm{T}_{90}$ (in ${ }^{\circ} \mathrm{C}$ ) obtained for the 100 combination of traits under the growing conditions 2005 and 2006. The dashed line corresponds to the 1:1 line.

\subsubsection{Future Growing Conditions}

To investigate the effects of likely future conditions, increases of temperature of $0^{\circ} \mathrm{C}$ to $10^{\circ} \mathrm{C}$ with respect to current conditions were combined with values of soil water potential ranging from -0.5 to $-3 \mathrm{MPa}$. Those changes were applied by considering both a standard day and a warm day of the 2005 growing season as baselines. 
Taking the currently normal thermal conditions as baseline, combination 3 (HP-HR) led to the highest assimilation rates under $\mathrm{T}_{\mathrm{A}}$ lower than $18^{\circ} \mathrm{C}$ (Figure 3 bottom row). For $\mathrm{T}_{\mathrm{A}}$ below $16^{\circ} \mathrm{C}, \mathrm{T}_{\mathrm{L}}$ reached temperatures similar to combinations 2 (HP-LR) and 4 (LP-LR). Combination 1 (LP-HR) led to the highest difference between $\mathrm{T}_{\mathrm{A}}$ and $\mathrm{T}_{\mathrm{L}}$, while combinations 2 (HP-LR), 3 (HP-HR) and 4 (LP-LR) showed similar $T_{L}$ values over a wide range of $T_{A}$ conditions (Figure 3 top row). $T_{L}$ was not sensitive to $\Psi_{\mathrm{S}}$ in any of the four combinations. The $\mathrm{A}_{\text {net }}$ contour curves showed a parabolic shape with a vertex in $\mathrm{T}_{\mathrm{A}}$ equal to $8^{\circ} \mathrm{C}, 10^{\circ} \mathrm{C}, 10^{\circ} \mathrm{C}$ and $12^{\circ} \mathrm{C}$ for combination $1,2,3$ and 4 , respectively.
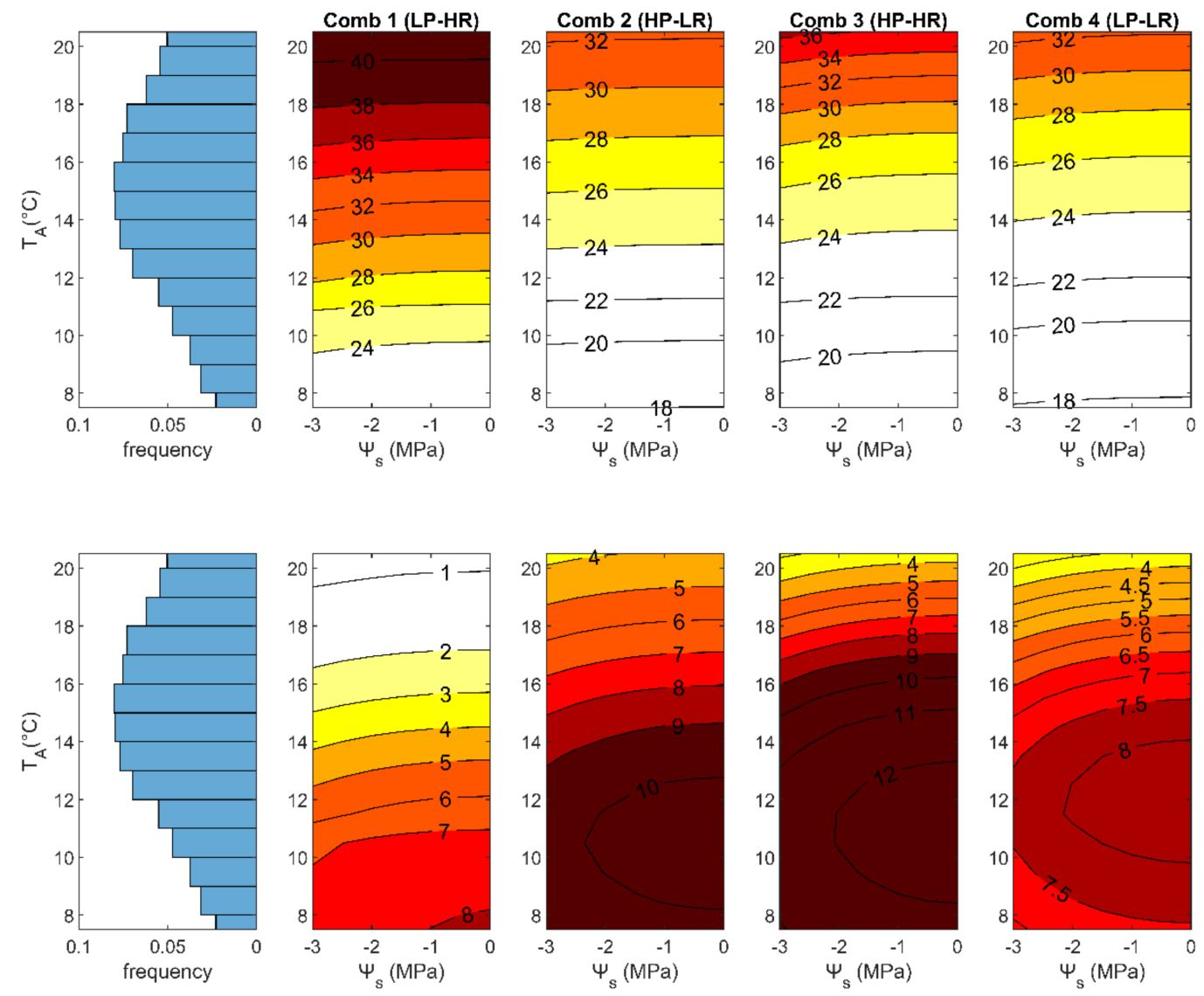

Figure 3. Leaf temperatures (top row; in ${ }^{\circ} \mathrm{C}$ ) and net assimilation rates (bottom row; in $\mu \mathrm{mol} \mathrm{m}^{-2} \mathrm{~s}^{-1}$ ) for different air temperatures and soil water potentials. Four trait combinations are explored (Table 2). The lowest air temperature corresponds to the median day for the growing season 2005. As a term of comparison, the left column shows the frequency of the air temperature at midday reported in the study site during the growing seasons from 1996 to 2016. LP-HR: Low Productivity-High Risk of thermal damage; HP-LR: High Productivity-Low Risk of thermal damage; HP-HR: High Productivity and High Risk of thermal damage; and LP-LR: Low Productivity and Low Risk of thermal damage.

For the warm day baseline conditions, combinations with high $1_{t}$-i.e., combinations 1 (LP-HR) and 3 (HP-HR) - were more likely to result in thermal damage, with $\mathrm{T}_{\mathrm{L}}$ exceeding $\mathrm{T}_{\mathrm{CRIT}}$ even under current thermal conditions (Figure 4 top row). Due to this high $\mathrm{T}_{\mathrm{L}}$, the assimilation rates were also reduced to the point that combination 3 (HP-HR) showed lower $\mathrm{A}_{\text {net }}$ even though its maximum assimilation rate was higher than the corresponding one in combination 4 (LP-LR) (Figure 4, bottom row). Conversely, combination 2 (HP-LR), and to some extent combination 4 (LP-LR), showed higher thermoregulation capacity (i.e., lower $\mathrm{T}_{\mathrm{L}}$ ) and higher assimilation rates. When compared, combination 2 (HP-LR) appeared to be more beneficial, resulting in lower $\mathrm{T}_{\mathrm{L}}$ and higher assimilation rates. Note that for all four combinations, an increase in $\mathrm{T}_{\mathrm{A}}$ with respect to the warm day baseline is detrimental to plant productivity, as $\mathrm{A}_{\text {net }}$ is reduced and leaves experience thermal damage already under current 
conditions (combination 1 and 3), or for temperature increases of 1 to $2.5^{\circ} \mathrm{C}$ (combination 4 and 2 , respectively). $\mathrm{T}_{\mathrm{L}}$ was sensitive to $\Psi_{\mathrm{S}}$ under dry conditions, particularly in combination 2 (HP-LR) (Figure 4 top row). Contrarily, in all combinations, $\mathrm{A}_{\text {net }}$ rates decreased as did water availability (Figure 4 bottom row).
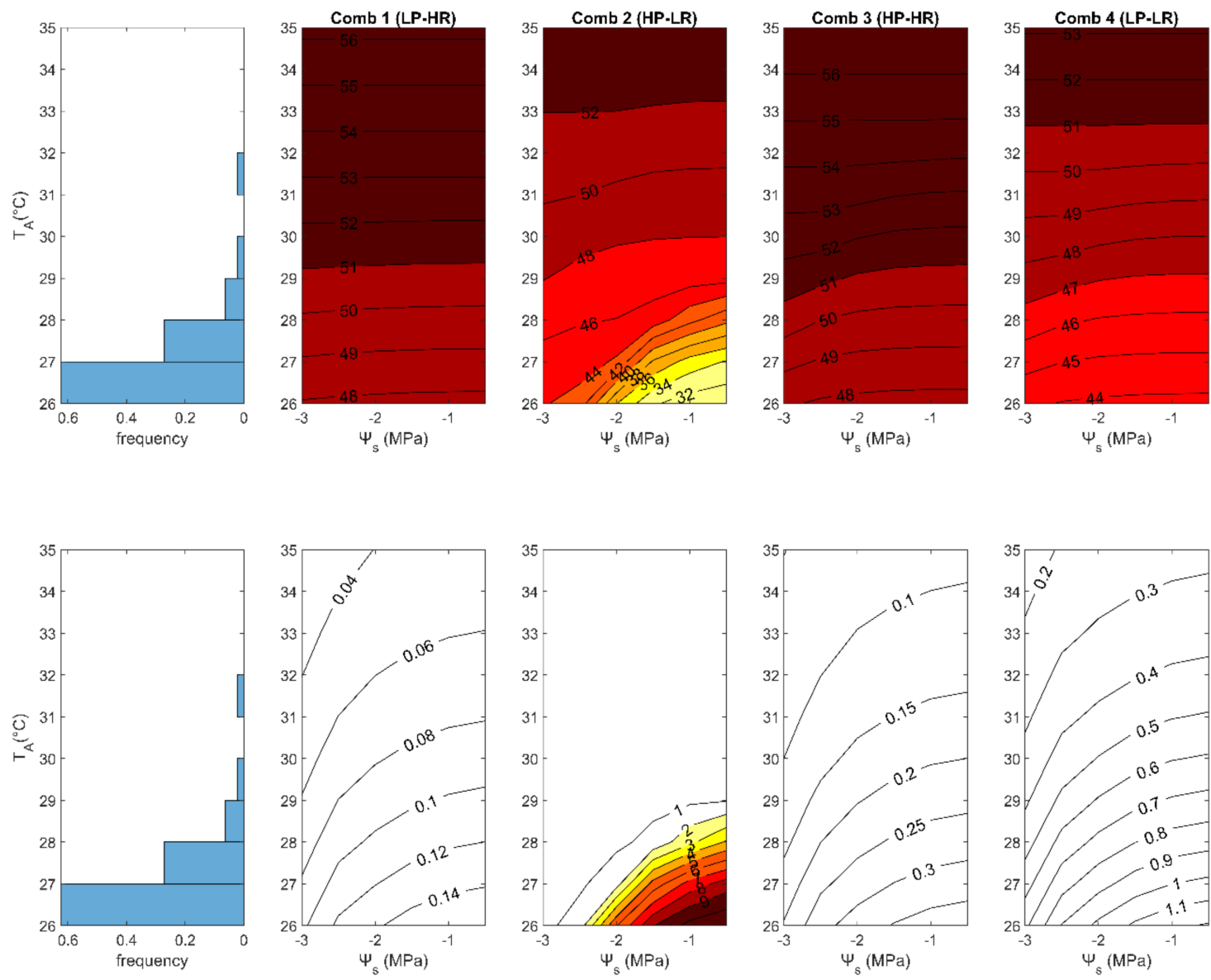

Figure 4. Leaf temperatures (top row; in ${ }^{\circ} \mathrm{C}$ ) and net assimilation rates (bottom row; in $\mu \mathrm{mol} \mathrm{m}^{-2} \mathrm{~s}^{-1}$ ) for different air temperatures and soil water potentials. The baseline temperature corresponds to the warmest day of the growing season 2005. All the other parameters are as in Figure 3.

Regarding the effects of plant traits on soil water depletion, similar $\Psi_{\mathrm{s}}$ emerged among the four trait combinations after the same number of consecutive days without precipitation. For all four combinations, after intervals shorter than 15 consecutive days without precipitation, soil water potential (i.e., lower $\Psi_{\mathrm{S}}$ ) was only slightly affected by increasing temperatures. The lowest $\Psi_{\mathrm{S}}$-around $-0.9 \mathrm{MPa}$ after more than 25 consecutive dry days-was reached by combination 2 (HP-LR) and 4 (LP-LR) (Figure 5). 

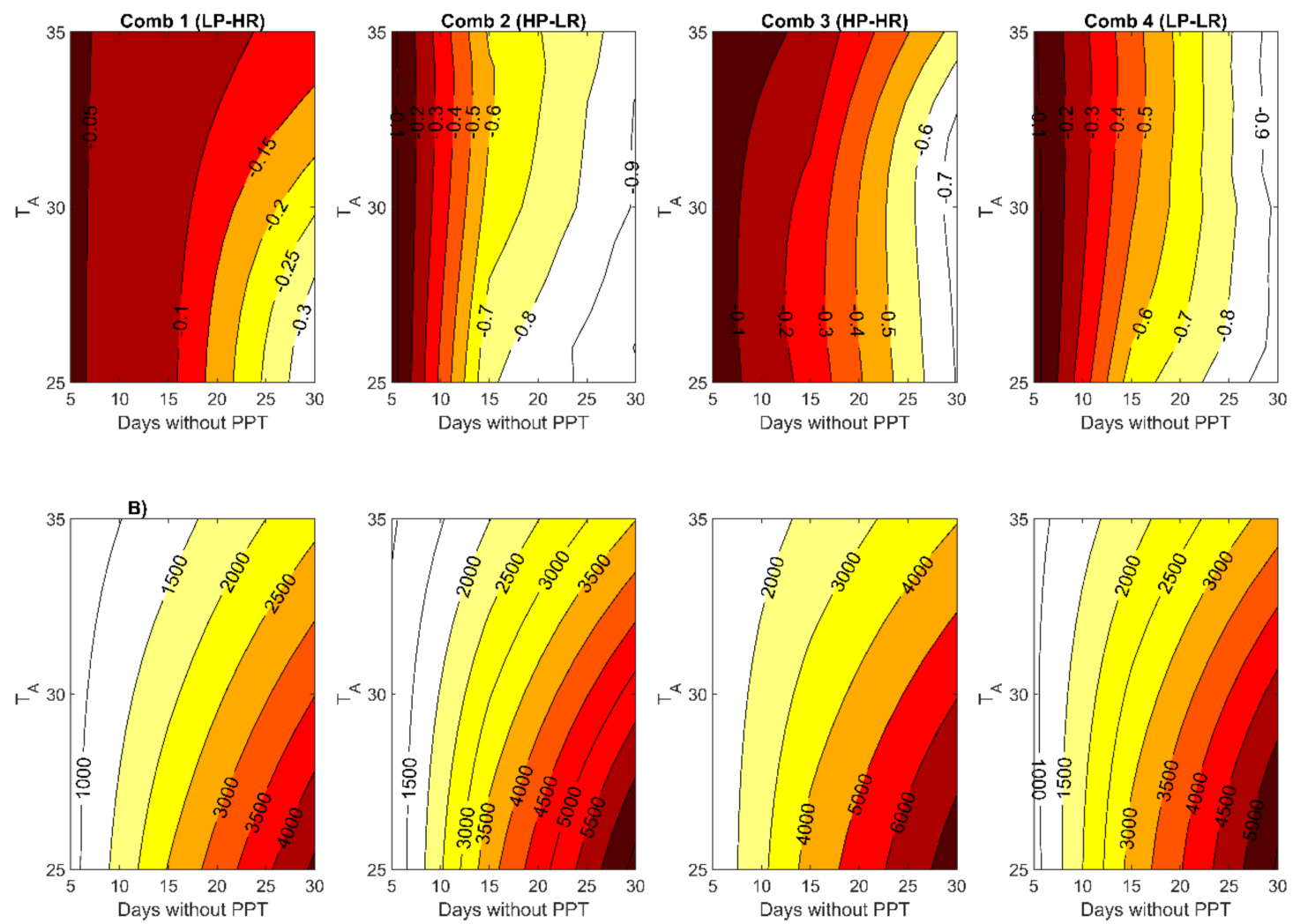

Figure 5. Soil water potential (upper panels; $\mathrm{MPa}$ ) and cumulated net assimilation (lower panels; $\mu \mathrm{mol}$ $\mathrm{m}^{-2} \mathrm{~s}^{-1}$ ) for each focal trait combination (Table 2) for specific $\mathrm{T}_{\mathrm{A}}$ (y-axis) and after a certain number of consecutive days without precipitation (x-axis). The baseline temperature corresponds to the warmest day in 2005. The rest of the growing conditions correspond to those observed in the study site during the same period within the growing season of 2005.

\section{Discussion}

\subsection{Role of Traits: Potential Mechanisms Explaining the Dominance of Plant Traits}

The GSA allowed identifying the role of six traits affecting net $\mathrm{CO}_{2}$ assimilation, $\mathrm{A}_{\text {net }}$, leaf temperature and $\mathrm{T}_{\mathrm{L}}$, and hence the risk of thermal damage. As expected, both the maximum and cumulated net $\mathrm{CO}_{2}$ assimilation are strongly dependent on the maximum carboxylation rate, $\mathrm{V}_{\mathrm{CMAX}, 25}$. They are also affected by the effective leaf thickness, $l_{t}$, although less markedly. In particular, higher $1_{t}$ values were also associated with higher cumulated net $\mathrm{CO}_{2}$ assimilation, $\mathrm{A}_{\text {net,cum }}$, but only up to $\mathrm{l}_{\mathrm{t}}$ $\sim 0.1 \mathrm{~m}$, above which this trend reverts. In general, higher $\mathrm{l}_{\mathrm{t}}$ leads to higher $\mathrm{T}_{\mathrm{L}}$, by reducing the leaf boundary layer conductance $g_{b}[60]$. Increase in $T_{L}$ may have opposite effects on $A_{\text {net }}$, depending on the initial temperature and the species: when $T_{L}$ is below the temperature that maximizes net $\mathrm{CO}_{2}$ assimilation, an increase in $\mathrm{T}_{\mathrm{L}}$ stimulates $\mathrm{A}_{\text {net }}$ [11]. In our results relative to current climates, $T_{L}$ was generally below such threshold, so that higher $l_{t}$ values were associated with higher $A_{\text {net,cum }}$. Nevertheless, as apparent from our results, there is a maximum $l_{t}$, above which increases in $l_{t}$ are no longer beneficial for $\mathrm{CO}_{2}$ assimilation because of an insufficient leaf cooling. Note that most boreal forests have needles, i.e., low $l_{t}$. It is important to note that plants grown in high light generally have thick leaves to protect them from high-irradiance damage [61,62]. Conversely, in low light available conditions (frequent in boreal forests), leaf thickness reduces to maximize the light capturing area and reduce self-shading. As such, the low $l_{t}$ typical of many boreal species enhances light use, and hence potentially net $\mathrm{CO}_{2}$ assimilation via light capture as opposed to optimal temperature for photosynthesis. Finally, within the range of values observed in mid-to-high latitudes (shaded area in Figure 1), the two 
parameters of the photosynthesis model $\left(\mathrm{g}_{1}, \beta\right)$, and both albedos $\left(\alpha_{\mathrm{PAR}}\right.$ and $\left.\alpha_{\mathrm{NIR}}\right)$ did not have any conspicuous influence on the net assimilation rates.

Regarding the thermal metrics, the range of high photosynthesis, $\Delta \mathrm{T}_{90} \mathrm{~W}$, was equally influenced by the traits $l_{t}, g_{1}$ and $V_{C M A X, 25}$. Conversely, the maximum temperature $T_{L, m a x}$, was mostly influenced by $l_{t}$, while $g_{1}$ and $V_{C M A X, 25}$ played secondary roles. In particular, lower $l_{t}$ values and higher $g_{1}$ values at a given $V_{C M A X, 25}$ lead to higher boundary layer and stomatal conductances, respectively, preventing thermal damage and resulting in lower $\mathrm{T}_{\mathrm{L}}$. Similarly, higher $\mathrm{V}_{\mathrm{CMAX}, 25}$ were associated to higher $\mathrm{g}_{\mathrm{S}}$, which in turn enhances the cooling effect of transpiration, resulting in lower $T_{L}$. This mechanism might explain the effect of $\mathrm{V}_{\mathrm{CMAX}, 25}$ on $\mathrm{T}_{\mathrm{L}, \max }$. However, with focus on values observed in mid-to-high latitudes (shaded area in Figure 1), the role of $\mathrm{V}_{\mathrm{CMAX}, 25}$ in regulating maximum $\mathrm{T}_{\mathrm{L}}$ diminished. Therefore, under warm conditions, the cooling effect of the transpiration process is generally neither benefited from nor hampered by the assimilation capacity of plants, but rather regulated by the traits $l_{t}$ and $\mathrm{g}_{1}$.

There is no evidence in the literature of how $\Delta \mathrm{T}_{90}$ changes according to plant traits, to the best of our knowledge. The width of the temperature range that realizes $>80 \%$ of the maximum photosynthetic rate varies among plant functional types, in particular at low growth temperatures $[1,63,64]$; however, thus far these differences have not been explained based on specific traits. Our results suggest that $\mathrm{V}_{\mathrm{CMAX}, 25}, \mathrm{l}_{\mathrm{t}}$ and $\mathrm{g}_{1}$ are the key traits that determine $\Delta \mathrm{T}_{90}$, possibly through the regulation of stomatal and boundary layer conductances. The influence of $\mathrm{V}_{\mathrm{CMAX}, 25}$ might also be due to the dependence of $\mathrm{V}_{\mathrm{CMAX}}$ on $\mathrm{T}_{\mathrm{L}}$ per se, as discussed in the Supplementary Materials. As apparent from Figure 1, leaves that are well coupled with the atmosphere (i.e., high $g_{b}$ and $g_{s}$ and, therefore, high $g_{1}$ and low $l_{t}$ ) correspond to wider $\Delta T_{90}$, whereas leaves less coupled with the atmosphere present narrower $\Delta T_{90}$. This might mirror two different plant strategies. Plants that are well coupled with the atmosphere respond more easily to changes on the atmospheric conditions so that $T_{L}$ fluctuates in a wider range than plants that are less coupled with the atmosphere. Therefore, plants that have lower assimilation rates and are well coupled have a wider range of optimal temperatures so that the lower assimilation rates and wider $T_{L}$ fluctuations are compensated by a wider range of semi-optimal conditions. In contrast, the ones with higher assimilation rates and less coupled with the atmosphere present a narrower range of optimal temperatures.

Briefly, $\mathrm{l}_{\mathrm{t}}, \mathrm{V}_{\mathrm{CMAX}, 25}$ and, to some extent, $\mathrm{g}_{1}$ are key for both assimilation rates and thermoregulation capacities, mainly via the regulation of stomatal and boundary layer conductances. With focus on mid-to-high latitudes, while $\mathrm{V}_{\mathrm{CMAX}, 25}$ has no large influence on the maximum temperature reached by plants under warm conditions, it is key on their thermoregulation capacity under normal conditions (Figure 1). Moreover, over this region, $\mathrm{g}_{1}$ has no effect on assimilation rates, which are completely dominated by $\mathrm{V}_{\mathrm{CMAX}, 25}$. Finally, the traits $\beta, \alpha_{\mathrm{PAR}}$ and $\alpha_{\mathrm{NIR}}$ seem to play secondary roles for all four metrics analyzed here and they will therefore not be further discussed.

It is important to acknowledge that the results of this analysis might slightly change if other growing conditions were to be used. However, this potential limitation is mitigated by the method employed to split the 100 combinations of traits between Group 1 and Group 2 (Section 2.3.2), which identifies suitable threshold irrespective of the model outputs. As such, similar conclusions on the relevance of the different traits would be drawn when considering other realistic growing conditions. A further aspect not accounted for here is thermal acclimation. Hence, assimilation rates and thermoregulation capacities and how they are influenced by the analyzed traits might change along with growth temperature, even in existing leaves, at scales of few days to weeks $[1,63]$. This might represent a limitation when comparing species exposed to contrasting growing conditions and/or with different acclimation capability. However, this analysis still provides key information by identifying the most dominant traits, their inter-relation and the potential mechanisms that explain plant responses. 


\subsection{Role of Growing Conditions: the Timing of Precipitatio Affects the Risk of Thermal Damage}

In combination with its inherent traits, plant $\mathrm{CO}_{2}$ assimilation and the risk of thermal damage are also determined by the environmental conditions. The contrasting weather conditions of the growing seasons 2005 and 2006 showed how the same combinations of traits led to different values for the four metrics. While no substantial differences were found in terms of maximum net $\mathrm{CO}_{2}$ assimilation rate, $\mathrm{A}_{\text {net,max }}$, and the range of high photosynthesis, $\Delta \mathrm{T}_{90}$, substantial differences emerged in terms of maximum temperature, $\mathrm{T}_{\mathrm{L} \text {,max }}$ and cumulated net $\mathrm{CO}_{2}$ assimilation, $\mathrm{A}_{\text {net,cum }}$ (Figure 2). Specifically, despite the lower mean air temperature and higher precipitation of 2005 over 2006, warm periods were more damaging in the growing season 2005 than 2006 regardless of the combination of traits (Figure 2). This difference can be ascribed to the timing of rainfall events: in 2005, the longest dry spell occurred during the warmest days, while this was not the case in 2006. As a result, in 2006, plants with sets of traits that reached thermal damage under growing conditions of 2005 could cope with similar or higher air temperatures and even benefit from these slightly warmer conditions, as photosynthetic capacity was enhanced and water was available for evaporative cooling to stave off the risk of thermal damage.

This result also emerges when exploring in more detail the combined effect of temperature and water availability as part of the future scenario analyses. While leaf temperature, $\mathrm{T}_{\mathrm{L}}$, was sensitive to soil water potential, $\Psi_{\mathrm{s}}$, under warm conditions (Figure 4, top row), $\mathrm{T}_{\mathrm{L}}$ did not show any substantial change with $\Psi_{\mathrm{s}}$ under normal ones (Figure 3, top row). Moreover, higher air temperature enhances soil water depletion but only under warm conditions (Figure 5, top row). These conclusions are not affected by the length of the growing season, which was held constant, since the aim is to identify differences in assimilation rates and leaf temperatures for different trait combinations but given the same abiotic conditions. The results highlight the relevance of the timing of high temperature and lower water availability and the importance of considering these events in conjunction [65-68]. The joint effects of high temperatures and low water availability are expected to become even more important in the future since high temperatures and water deficiency during the growing season are likely to become more frequent in boreal regions [69]. Hence, there will be a likely increase in the probability that boreal forests will need to cope with more severe combination of heat waves and droughts [15].

\subsection{Interactions of Traits and Growing Conditions: Most Suitable Traits for Enhanced $\mathrm{CO}_{2}$ Assimilation and Reduced Risk of Thermal Damage Under Current and Future Climates}

Within the general pattern discussed above, specific trait sets can reduce or enhance thermal risks in specific climatic conditions. Therefore, attempts to identify the set of traits that could maximize productivity while preventing thermal damage under current and future conditions necessarily require the joint analysis of traits and specific growing conditions. Thus, we tested four combination of traits that presented contrasting assimilation and thermal responses during the 2005 growing season-a normal season at the reference site-and analyzed their response under multiple scenarios of future climatic conditions. The values for each trait within each combination are restricted to those observed in boreal tree species-in line with our focus on boreal forests- to account for the fact that trait values per se are related to climatic conditions. For example, global $\mathrm{V}_{\mathrm{CMAX}, 25}$ distribution has been recently proved to be mainly explained by climate [70].

As discussed in Section 4.2, the combination of low water availability and heat stress causes a disproportionate damage compared to each stress component occurring in isolation [65,66,71-73]. Due to the compound effect of low water availability and high temperatures, the focus of the multi-scenarios assessment was on these abiotic stressors, holding constant (i.e., as observed in 2005) the other climatic variables (chiefly, relative humidity, wind speed and atmospheric $\mathrm{CO}_{2}$ concentration). Nevertheless, reduced wind speed may lead to a further decoupling of leaf and air temperature, with potentially high and damaging temperatures in sunlit leaves. Declines of long-term wind speed (stilling) have been reported in both hemispheres [74,75]. Therefore, all else being equal, even higher leaf temperatures, $\mathrm{T}_{\mathrm{L}}$, are to be expected as the result of the reduced cooling due to stilling, in particular for leaves with 
large effective leaf thickness $1_{t}$. Similarly, the stomatal closure potentially caused by enhanced $\mathrm{CO}_{2}$ concentration may further increase $\mathrm{T}_{\mathrm{L}}$.

Our model results clearly show that, during the warmest period of the growing season, future warmer and drier conditions may cause reductions in net $\mathrm{CO}_{2}$ assimilation $\mathrm{A}_{\text {net }}$ regardless of plant traits (Figure 4 bottom row). Conversely, during periods with lower air temperatures, warming temperatures might be still beneficial (Figure 3 bottom row). However, the analysis of temperature data over the period 1996-2006 (upper row histogram in Figure 3) shows that, for the site of reference, higher temperatures were either not beneficial for productivity or even harmful in $75 \%$ to $93 \%$ of the days of the growing season depending on the trait combination. Similarly, future warmer and drier conditions may substantially increase the risk of thermal damage regardless of the plant traits. Nonetheless, how damaging these new conditions are depends on the trait set (Figure 4, upper row).

The GSA clearly shows that high photosynthetic capacity (i.e., high maximum carboxylation rate, $V_{C M A X, 25}$ is needed to ensure high $A_{n e t}$; small $l_{t}$ is the key trait to prevent thermal damage. Under the growing conditions of 2005, enhancement of cumulated net $\mathrm{CO}_{2}$ assimilation $\mathrm{A}_{\text {net,cum }}$ emerges when $\mathrm{V}_{\mathrm{CMAX}, 25}$ increases, as apparent when comparing the $\mathrm{A}_{\text {net,cum }}$ for combination 1 (Low Productivity-High Risk; LP-HR) and combination 4 (Low Productivity-Low Risk, LP-LR) against combinations 2 (High Productivity-Low Risk; HP-LR) and 3 (High Productivity-High Risk; HP-HR) (Table 2). Indeed, under standard conditions, the combination with the highest $\mathrm{V}_{\mathrm{CMAX}, 25}$ (combination 3; HP-HR) showed the highest $\mathrm{A}_{\text {net }}$ (Figure 3 bottom row). However, this enhancement does not hold under warm conditions: in this case, assimilation rate is also limited by leaf temperature as the optimal temperature for photosynthesis is exceeded (Figure 4 bottom row). Temperatures above this threshold might constrain assimilation rates to the extent that plants with high $\mathrm{V}_{\mathrm{CMAX}, 25}$ can show lower assimilation rates than plants with lower $\mathrm{V}_{\mathrm{CMAX}, 25}$, as apparent by comparing combination 4 (LP-LR) versus combination 3 (HP-HR) under the warmest conditions within the growing season. This pattern is also partly due to the sensitivity to temperature of $V_{C M A X}$ increasing with $V_{C M A X, 25}$. Moreover, lower $\mathrm{V}_{\mathrm{CMAX}, 25}$ was also associated with broader the range of high photosynthesis $\Delta \mathrm{T}_{90}$, i.e., a broader range of conditions that allow high assimilation rates. In fact, only those plants with the ability to be well-coupled with the atmosphere (i.e., low $l_{t}$ ) can keep high assimilation rates as shown by combination 2 (HP-LR) and, to a lower extent, combination 4 (LP-LR) (Figure 4 bottom row), even though the former has substantially higher assimilation rates and lower $\mathrm{T}_{\mathrm{L}}$ than the latter.

Nonetheless, combination 3 (HP-HR), which has high $l_{t}$, was the one with the highest $A_{\text {net,cum }}$ within the growing season 2005. This is because, up to air temperature $\mathrm{T}_{\mathrm{A}}$ around $18{ }^{\circ} \mathrm{C}$, combination 3 (HP-HR) shows the highest $\mathrm{A}_{\text {net }}$ (Figure 3 bottom row). Based on the observed $\mathrm{T}_{\mathrm{A}}$ at midday in the reference site during the growing seasons in $1996-2016, \mathrm{~T}_{\mathrm{A}}$ was lower than $18^{\circ} \mathrm{C}$ in the $70.3 \%$ of days, making combination 3 (HP-HR) the most appealing one in terms of overall productivity. However, this combination can also lead to thermal damage (i.e., $\mathrm{T}_{\mathrm{L}}$ exceeding the critical temperature for leaf damage, $\mathrm{T}_{\mathrm{CRIT}}$; Section 2.3.2) for $\mathrm{T}_{\mathrm{A}} \geq 26^{\circ} \mathrm{C}$, particularly under limited water availability (Figure 4 top row). The maximum $\mathrm{T}_{\mathrm{A}}$ at midday reported in the reference site exceeded this value in half the years between 1996 and 2016 (Figure 4, top left). Therefore, high $l_{t}$ might be beneficial for assimilation over the growing season at the expense of increasing the likelihood of thermal damage, particularly under water stress. Indeed, across all plant types, leaf size is distributed geographically according to a combination of the mean temperature of the warmest month of the year and the mean annual precipitation: higher mean temperature in the warmest month and lower mean annual precipitation correspond to smaller leaf sizes [76]. Thus, the selection of $l_{t}$ is not straightforward since it might represent a trade-off between productivity and prevention of thermal damage. The net result depends largely on the climatic conditions.

As explained in the Methods, the trait combinations were generated randomly because this study aimed to identify the role of each trait when combined with other traits and under specific growing conditions. Thus, the trait combinations do not to represent specific species. However, the combination of traits that leads to the highest thermal damage risk and/or is more likely to experience sub-optimal 
conditions for assimilation can be used to speculate which species are likely to be more vulnerable to future growing conditions. For example, Pinus sylvestris L. and Picea abies L.- the two dominant species in Northern Europe - have small and rounded needle leaves (i.e., low effective leaf thickness $1_{t}$ ) in common but Pinus sylvestris L. usually exhibits higher photosynthetic capacity (i.e., higher $\mathrm{V}_{\mathrm{CMAX}, 25}$ ) than Picea abies L. e.g., [77]. Although our results are not aimed to be representative of specific boreal species, Pinus sylvestris L. can be considered similar to combinations 2 (HP-LR) and Picea abies L. to combination 4 (LP-LR). As such, based on our conclusions, one could expect Picea abies L. to be more vulnerable to warming climates than Pinus sylvestris L., even suffering thermal damage under current conditions. Indeed, negative effects of warming on Picea abies L. species have been already reported [78], while Pinus sylvestris L. appears less sensitive to warming [79,80].

\section{Conclusions}

Understanding how specific plant traits, and combination of traits, prevent or enhance heat stress and $C$ uptake is vital to predict how projected increases in frequency of heat waves and droughts in future climate may affect boreal forests. To disentangle the role of plant traits on thermoregulation and $C$ uptake, we focused on six traits: the maximum carboxylation rate, two parameters that regulate the stomatal conductance and its sensibility to water stress, the effective leaf thickness and the PAR and NIR albedos. Four performance metrics related to leaf temperature and assimilation were evaluated, with a focus on the growing season.

Among the analyzed traits, photosynthetic capacity (as represented by maximum carboxylation rate at $\left.25{ }^{\circ} \mathrm{C}, \mathrm{V}_{\mathrm{CMAX}, 25}\right)$ and the effective leaf thickness, $1_{t}$, were the dominant ones regarding both thermoregulation and assimilation. Higher values of $\mathrm{V}_{\mathrm{CMAX}, 25}$ are needed to enhance assimilation under current and future conditions. To prevent thermal damage, high $\mathrm{V}_{\mathrm{CMAX}, 25}$ should be combined with low $l_{t}$. However, the selection between low or high $l_{t}$ is not straightforward since $l_{t}$ seems to represent a trade-off between thermal damage prevention and productivity.

Moreover, the climate change scenario analyses highlighted that the projected joint changes in temperature and water availability needs to be considered in our prognosis of future boreal forest wellbeing, because combination of traits that prevent thermal damage under current growing conditions will not be able to limit the occurrence of thermal damage under warmer and/or drier conditions. Likewise, substantial differences were observed when considering currently normal versus warm conditions within the same growing season. This suggests that trait selection should not only rely on the overall productivity over the whole growing season but should also consider specifically the warmest period.

Further analyses exploiting databases of traits and how they are distributed geographically and regional projections of growing conditions, combined with the understanding of the role played by plant traits provided by our results, can support the identification of species and regions most vulnerable to climate change, where appropriate forest management should be focused.

Supplementary Materials: The following are available online at http://www.mdpi.com/1999-4907/10/5/398/s1, Supplementary Materials document.

Author Contributions: This article is the result of the joint effort between G.R.-P., G.V. and S.L. The tasks were divided as follows: conceptualization, G.R.-P., G.V. and S.L.; methodology, G.R.-P. and G.V.; software, S.L.; validation, G.R.-P. and G.V.; formal analysis, G.R.-P.; investigation, G.R.-P. and G.V.; resources, G.V. and S.L.; writing—original draft preparation, G.R.-P.; writing—review and editing, G.R.-P., G.V. and S.L. supervision, G.V. and S.L.; and funding acquisition, G.V.

Funding: This research was supported by the Swedish Research Council Formas through grant 2018-01820 and by the Swedish government through the project Trees and Crops for the Future (TC4F). S.L. was also supported by the Academy of Finland, through the Academy Research Fellow project CLIMOSS (No. 296116 and 307192).

Conflicts of Interest: The authors declare no conflict of interest. The funders had no role in the design of the study; in the collection, analyses, or interpretation of data; in the writing of the manuscript, or in the decision to publish the results. 


\section{References}

1. Yamori, W.; Hikosaka, K.; Way, D.A. Temperature response of photosynthesis in C-3, C-4, and CAM plants: Temperature acclimation and temperature adaptation. Photosynth. Res. 2014, 119, 101-117. [CrossRef]

2. Hasanuzzaman, M.; Nahar, K.; Alam, M.M.; Roychowdhury, R.; Fujita, M. Physiological, Biochemical, and Molecular Mechanisms of Heat Stress Tolerance in Plants. Int. J. Mol. Sci. 2013, 14, 9643-9684. [CrossRef] [PubMed]

3. O'Sullivan, O.S.; Heskel, M.A.; Reich, P.B.; Tjoelker, M.G.; Weerasinghe, L.K.; Penillard, A.; Zhu, L.L.; Egerton, J.J.G.; Bloomfield, K.J.; Creek, D.; et al. Thermal limits of leaf metabolism across biomes. Glob. Chang. Biol. 2017, 23, 209-223. [CrossRef] [PubMed]

4. Schreiber, U.; Berry, J.A. Heat-induced changes of chlorophyll fluorescence in intact leaves correlated with damage of the photosynthetic apparatus. Planta 1977, 136, 233-238. [CrossRef]

5. Huve, K.; Bichele, I.; Rasulov, B.; Niinemets, U. When it is too hot for photosynthesis: Heat-induced instability of photosynthesis in relation to respiratory burst, cell permeability changes and $\mathrm{H} 2 \mathrm{O} 2$ formation. Plant Cell Environ. 2011, 34, 113-126. [CrossRef] [PubMed]

6. Knight, C.A.; Ackerly, D.D. Evolution and plasticity of photosynthetic thermal tolerance, specific leaf area and leaf size: Congeneric species from desert and coastal environments. New Phytol. 2003, 160, 337-347. [CrossRef]

7. O'Sullivan, O.S.; Weerasinghe, K.W.L.K.; Evans, J.R.; Egerton, J.J.G.; Tjoelker, M.G.; Atkin, O.K. High-resolution temperature responses of leaf respiration in snow gum (Eucalyptus pauciflora) reveal high-temperature limits to respiratory function. Plant, Cell 2013, 36, 1268-1284. [CrossRef]

8. Chaves, M.; Costa, J.; Zarrouk, O.; Pinheiro, C.; Lopes, C.; Pereira, J.; Costa, J. Controlling stomatal aperture in semi-arid regions-The dilemma of saving water or being cool? Plant Sci. 2016, 251, 54-64. [CrossRef]

9. Monteiro, M.V.; Blanuša, T.; Verhoef, A.; Hadley, P.; Cameron, R.W.F. Relative importance of transpiration rate and leaf morphological traits for the regulation of leaf temperature. Aust. J. Bot. 2016, 64, 32. [CrossRef]

10. Radin, J.W.; Lu, Z.; Percy, R.G.; Zeiger, E. Genetic variability for stomatal conductance in Pima cotton and its relation to improvements of heat adaptation. Proc. Natl. Acad. Sci. USA 1994, 91, 7217-7221. [CrossRef]

11. Okajima, Y.; Taneda, H.; Noguchi, K.; Terashima, I. Optimum leaf size predicted by a novel leaf energy balance model incorporating dependencies of photosynthesis on light and temperature. Ecol. Res. 2012, 27, 333-346. [CrossRef]

12. Vogel, S. Leaves in the lowest and highest winds: temperature, force and shape. New Phytol. 2009, 183, 13-26. [CrossRef]

13. Leigh, A.; Sevanto, S.; Ball, M.C.; Close, J.D.; Ellsworth, D.S.; Knight, C.A.; Nicotra, A.B.; Vogel, S. Do thick leaves avoid thermal damage in critically low wind speeds? New Phytol. 2012, 194, 477-487. [CrossRef]

14. Luquet, D.; Bégué, A.; Vidal, A.; Clouvel, P.; Dauzat, J.; Olioso, A.; Gu, X.; Tao, Y. Using multidirectional thermography to characterize water status of cotton. Remote. Sens. Environ. 2003, 84, 411-421. [CrossRef]

15. Intergovernmental Panel on Climate Change. Climate Change 2014_Impacts, Adaptation and Vulnerability: Part B: Regional Aspects; Cambridge University Press: Cambridge, UK, 2014.

16. Allen, C.D.; Macalady, A.K.; Chenchouni, H.; Bachelet, D.; McDowell, N.; Vennetier, M.; Kitzberger, T.; Rigling, A.; Breshears, D.D.; Hogg, E. (Ted); et al. A global overview of drought and heat-induced tree mortality reveals emerging climate change risks for forests. Ecol. Manag. 2010, 259, 660-684. [CrossRef]

17. Boisvenue, C.; Running, S.W. Impacts of climate change on natural forest productivity-Evidence since the middle of the 20th century. Chang. Boil. 2006, 12, 862-882. [CrossRef]

18. Sastry, A.; Barua, D. Leaf thermotolerance in tropical trees from a seasonally dry climate varies along the slow-fast resource acquisition spectrum. Sci. Rep. 2017, 7, 11246. [CrossRef]

19. Bonan, G.B. Forests and Climate Change: Forcings, Feedbacks, and the Climate Benefits of Forests. Science 2008, 320, 1444-1449. [CrossRef]

20. Pan, Y.; Birdsey, R.A.; Fang, J.; Houghton, R.; Kauppi, P.E.; Kurz, W.A.; Phillips, O.L.; Shvidenko, A.; Lewis, S.L.; Canadell, J.G.; et al. A Large and Persistent Carbon Sink in the World's Forests. Science 2011, 333, 988-993. [CrossRef]

21. Baul, T.K.; Alam, A.; Ikonen, A.; Strandman, H.; Asikainen, A.; Peltola, H.; Kilpeläinen, A. Climate Change Mitigation Potential in Boreal Forests: Impacts of Management, Harvest Intensity and Use of Forest Biomass to Substitute Fossil Resources. Forests 2017, 8, 455. [CrossRef] 
22. Grossiord, C.; Sevanto, S.; Adams, H.D.; Collins, A.D.; Dickman, L.T.; McBranch, N.; Michaletz, S.T.; Stockton, E.A.; Vigil, M.; McDowell, N.G. Precipitation, not air temperature, drives functional responses of trees in semi-arid ecosystems. J. Ecol. 2017, 105, 163-175. [CrossRef]

23. Helman, D.; Osem, Y.; Yakir, D.; Lensky, I.M. Relationships between climate, topography, water use and productivity in two key Mediterranean forest types with different water-use strategies. Agric. Meteorol. 2017, 232, 319-330. [CrossRef]

24. Grossiord, C.; Granier, A.; Gessler, A.; Jucker, T.; Bonal, D. Does Drought Influence the Relationship Between Biodiversity and Ecosystem Functioning in Boreal Forests? Ecosystems 2014, 17, 394-404. [CrossRef]

25. Aubin, I.; Munson, A.; Cardou, F.; Burton, P.; Isabel, N.; Pedlar, J.; Paquette, A.; Taylor, A.; Delagrange, S.; Kebli, H.; et al. Traits to stay, traits to move: a review of functional traits to assess sensitivity and adaptive capacity of temperate and boreal trees to climate change. Environ. Rev. 2016, 24, 164-186. [CrossRef]

26. Girardin, M.P.; Bouriaud, O.; Hogg, E.H.; Kurz, W.; Zimmermann, N.E.; Metsaranta, J.M.; de Jong, R.; Frank, D.C.; Esper, J.; Buntgen, U.; et al. No growth stimulation of Canada's boreal forest under half-century of combined warming and CO2 fertilization. Proc. Natl. Acad. Sci. USA 2016, 113, E8406-E8414. [CrossRef]

27. O’Brien, M.J.; Engelbrecht, B.M.J.; Joswig, J.; Pereyra, G.; Schuldt, B.; Jansen, S.; Kattge, J.; Landhäusser, S.M.; Levick, S.R.; Preisler, Y.; et al. A synthesis of tree functional traits related to drought-induced mortality in forests across climatic zones. J. Appl. Ecol. 2017, 54, 1669-1686. [CrossRef]

28. Launiainen, S.; Katul, G.G.; Kolari, P.; Lindroth, A.; Lohila, A.; Aurela, M.; Varlagin, A.; Grelle, A.; Vesala, T. Do the energy fluxes and surface conductance of boreal coniferous forests in Europe scale with leaf area? Chang. Boil. 2016, 22, 4096-4113. [CrossRef]

29. Launiainen, S.; Katul, G.G.; Laurén, A.; Kolari, P. Coupling boreal forest CO2, H2O and energy flows by a vertically structured forest canopy - Soil model with separate bryophyte layer. Ecol. Model. 2015, 312, 385-405. [CrossRef]

30. Farquhar, G.D.; Von Caemmerer, S.; Berry, J.A. A biochemical model of photosynthetic CO2 assimilation in leaves of C3 species. Planta 1980, 149, 78-90. [CrossRef]

31. Medlyn, B.E.; Dreyer, E.; Ellsworth, D.; Forstreuter, M.; Harley, P.C.; Kirschbaum, M.U.F.; Le Roux, X.; Montpied, P.; Strassemeyer, J.; Walcroft, A.; et al. Temperature response of parameters of a biochemically based model of photosynthesis. II. A review of experimental data. Plant Cell Environ. 2002, 25, 1167-1179. [CrossRef]

32. Kellomäki, S.; Wang, K.-Y. Photosynthetic responses to needle water potentials in Scots pine after a four-year exposure to elevated CO2 and temperature. Tree Physiol. 1996, 16, 765-772. [CrossRef] [PubMed]

33. Medlyn, B.E.; Duursma, R.A.; Eamus, D.; Ellsworth, D.; Prentice, I.C.; Barton, C.V.M.; Crous, K.Y.; De Angelis, P.; Freeman, M.; Wingate, L. Reconciling the optimal and empirical approaches to modelling stomatal conductance. Chang. Boil. 2011, 17, 2134-2144. [CrossRef]

34. Zhao, W.; Qualls, R.J. A multiple-layer canopy scattering model to simulate shortwave radiation distribution within a homogeneous plant canopy. N.a. Resour. 2005, 41. [CrossRef]

35. Zhao, W.; Qualls, R.J. Modeling of long-wave and net radiation energy distribution within a homogeneous plant canopy via multiple scattering processes. N.a. Resour. 2006, 42. [CrossRef]

36. Schuepp, P.H. Tansley Review No. 59 Leaf Boundary-Layers. New Phytol. 1993, 125, 477-507. [CrossRef]

37. Campbell, G.S.; Norman, J.M. An Introduction to Environmental Biophysics; Springer Nature: Basingstoke, UK, 1998.

38. Medlyn, B.E.; Badeck, F.W.; De Pury, D.G.G.; Barton, C.V.M.; Broadmeadow, M.; Ceulemans, R.; De Angelis, P.; Forstreuter, M.; Jach, M.E.; Kellomaki, S.; et al. Effects of elevated [CO2] on photosynthesis in European forest species: a meta-analysis of model parameters. Plant Cell Eniviron. 1999, 22, 1475-1495. [CrossRef]

39. Baldocchi, D.; Meyers, T. On using eco-physiological, micrometeorological and biogeochemical theory to evaluate carbon dioxide, water vapor and trace gas fluxes over vegetation: A perspective. Agric. Meteorol. 1998, 90, 1-25. [CrossRef]

40. Kattge, J.; Knorr, W. Temperature acclimation in a biochemical model of photosynthesis: A reanalysis of data from 36 species. Plant Cell 2007, 30, 1176-1190. [CrossRef]

41. Beerling, D.; Quick, W. A new technique for estimating rates of carboxylation and electron transport in leaves of C3 plants for use in dynamic global vegetation models. Chang. Boil. 1995, 1, 289-294. [CrossRef] 
42. Aerts, R.; Brovkin, V.; Cavender-Bares, J.; Cavender-Bares, J.; Verheijen, L.M.; Cornelissen, J.H.C.; Kattge, J.; Van Bodegom, P.M. Inclusion of ecologically based trait variation in plant functional types reduces the projected land carbon sink in an earth system model. Chang. Boil. 2015, 21, 3074-3086.

43. A Arain, M.; A Black, T.; Barr, A.G.; Jarvis, P.G.; Massheder, J.M.; Verseghy, D.L.; Nesic, Z. Effects of seasonal and interannual climate variability on net ecosystem productivity of boreal deciduous and conifer forests. Can. J. 2002, 32, 878-891. [CrossRef]

44. Medlyn, B.E.; Berbigier, P.; Clement, R.; Grelle, A.; Loustau, D.; Linder, S.; Wingate, L.; Jarvis, P.G.; Sigurdsson, B.D.; McMurtrie, R.E. Carbon balance of coniferous forests growing in contrasting climates: Model-based analysis. Agric. Meteorol. 2005, 131, 97-124. [CrossRef]

45. Niinemets, Ülo Research review. Components of leaf dry mass per area - thickness and density - alter leaf photosynthetic capacity in reverse directions in woody plants. New Phytol. 1999, 144, 35-47. [CrossRef]

46. Niinemets, Ülo GLOBAL-SCALE CLIMATIC CONTROLS OF LEAF DRY MASS PER AREA, DENSITY, AND THICKNESS IN TREES AND SHRUBS. Ecology 2001, 82, 453-469. [CrossRef]

47. Lin, Y.-S.; Medlyn, B.E.; Duursma, R.A.; Prentice, I.C.; Wang, H.; Baig, S.; Eamus, D.; de Dios „, V.R.; Mitchell, P.; Ellsworth, D.S.; et al. Optimal stomatal behaviour around the world. Nat. Clim. Change 2015, 5, 459. [CrossRef]

48. Breuer, L.; Eckhardt, K.; Frede, H.-G. Plant parameter values for models in temperate climates. Ecol. Model. 2003, 169, 237-293. [CrossRef]

49. Bartlett, M.K.; Ollinger, S.V.; Wicklein, H.F.; Hollinger, D.Y.; Richardson, A.D. Canopy-scale relationships between foliar nitrogen and albedo are not observed in leaf reflectance and transmittance within temperate deciduous tree species. Botany 2011, 89, 491-497. [CrossRef]

50. Dickinson, R.E. Land Surface Processes and Climate-Surface Albedos and Energy Balance. Adv. Geophys. 1983, 25, 305-353.

51. Hornberger, G.M.; Spear, R.C. Eutrophication in Peel Inlet.1. Problem-Defining Behavior and a Mathematical-Model for the Phosphorus Scenario. Water Res. 1980, 14, 29-42. [CrossRef]

52. McIntyre, N.; Jackson, B.; Wade, A.; Butterfield, D.; Wheater, H.; Wade, A. Sensitivity analysis of a catchment-scale nitrogen model. J. Hydrol. 2005, 315, 71-92. [CrossRef]

53. Medici, C.; Wade, A.; Frances, F.; Wade, A. Does increased hydrochemical model complexity decrease robustness? J. Hydrol. 2012, 440, 1-13. [CrossRef]

54. Ruiz-Pérez, G.; Medici, C.; Latron, J.; Llorens, P.; Gallart, F.; Francès, F.; Ruiz-Pérez, G. Investigating the behaviour of a small Mediterranean catchment using three different hydrological models as hypotheses. Hydrol. Process. 2016, 30, 2050-2062. [CrossRef]

55. Kolari, P.; Kulmala, L.; Pumpanen, J.; Launiainen, S.; Ilvesniem, H.; Hari, P.; Nikinmaa, E. CO2 exchange and component CO2 fluxes of a boreal Scots pine forest. Boreal Environ. Res. 2009, 14, 761-783.

56. Kulmala, L.; Launiainen, S.; Pumpanen, J.; Lankreijer, H.; Lindroth, A.; Hari, P.; Vesala, T. H2O and CO2fluxes at the floor of a boreal pine forest. N.a. B: Chem. Phys. Meteorol. 2008, 60, 167-178.

57. Gao, Y.; Markkanen, T.; Aurela, M.; Mammarella, I.; Thum, T.; Tsuruta, A.; Yang, H.; Aalto, T. Response of water use efficiency to summer drought in a boreal Scots pine forest in Finland. Biogeosciences 2017, 14, 4409-4422. [CrossRef]

58. Richardson, A.D.; Keenan, T.F.; Migliavacca, M.; Ryu, Y.; Sonnentag, O.; Toomey, M. Climate change, phenology, and phenological control of vegetation feedbacks to the climate system. Agric. Meteorol. 2013, 169, 156-173. [CrossRef]

59. Gill, A.L.; Gallinat, A.S.; Sanders-DeMott, R.; Rigden, A.J.; Gianotti, D.J.S.; Mantooth, J.A.; Templer, P.H. Changes in autumn senescence in northern hemisphere deciduous trees: A meta-analysis of autumn phenology studies. Ann. Bot. 2015, 116, 875-888. [CrossRef]

60. Michaletz, S.T.; Weiser, M.D.; McDowell, N.G.; Zhou, J.; Kaspari, M.; Helliker, B.R.; Enquist, B.J. Corrigendum: The energetic and carbon economic origins of leaf thermoregulation. Nat. Plants 2016, 2, 16147. [CrossRef]

61. Davi, H.; Barbaroux, C.; Dufrene, E.; François, C.; Montpied, P.; Breda, N.; Badeck, F. Modelling leaf mass per area in forest canopy as affected by prevailing radiation conditions. Ecol. Model. 2008, 211, 339-349. [CrossRef]

62. Xu, F.; Guo, W.; Xu, W.; Wei, Y.; Wang, R. Leaf morphology correlates with water and light availability: What consequences for simple and compound leaves? Prog. Sci. Mater. Int. 2009, 19, 1789-1798. [CrossRef] 
63. Vico, G.; Way, D.A.; Hurry, V.; Manzoni, S. Can leaf net photosynthesis acclimate to rising and more variable temperatures? Plant Cell Environ. 2019. [CrossRef]

64. Way, D.A.; Yamori, W. Thermal acclimation of photosynthesis: On the importance of adjusting our definitions and accounting for thermal acclimation of respiration. Photosynth. Res. 2014, 119, 89-100. [CrossRef]

65. Barnabas, B.; Jager, K.; Feher, A. The effect of drought and heat stress on reproductive processes in cereals. Plant Cell Environ. 2008, 31, 11-38. [CrossRef] [PubMed]

66. De Boeck, H.J.; Bassin, S.; Verlinden, M.; Zeiter, M.; Hiltbrunner, E. Simulated heat waves affected alpine grassland only in combination with drought. New Phytol. 2016, 209, 531-541. [CrossRef]

67. Suzuki, N.; Rivero, R.M.; Shulaev, V.; Blumwald, E.; Mittler, R. Abiotic and biotic stress combinations. New Phytol. 2014, 203, 32-43. [CrossRef]

68. Zscheischler, J.; Westra, S.; van den Hurk, B.J.J.M.; Seneviratne, S.I.; Ward, P.J.; Pitman, A.; AghaKouchak, A.; Bresch, D.N.; Leonard, M.; Wahl, T.; et al. Future climate risk from compound events. Nat. Clim. Chang. 2018, 8, 469-477. [CrossRef]

69. Belyazid, S.; Giuliana, Z. Water limitation can negate the effect of higher temperatures on forest carbon sequestration. Eur. J. 2019, 138, 287-297. [CrossRef]

70. Smith, N.G.; Keenan, T.F.; Prentice, I.C.; Wang, H.; Wright, I.J.; Niinemets, Ü.; Crous, K.Y.; Domingues, T.F.; Guerrieri, R.; Ishida, F.Y.; et al. Global photosynthetic capacity is optimized to the environment. Ecol. Lett. 2019, 22, 506-517. [CrossRef] [PubMed]

71. Keleş, Y.; Öncel, I. Response of antioxidative defence system to temperature and water stress combinations in wheat seedlings. N.a. Sci. 2002, 163, 783-790. [CrossRef]

72. Rizhsky, L.; Liang, H.; Mittler, R. The Combined Effect of Drought Stress and Heat Shock on Gene Expression in Tobacco1. N.a. Physiol. 2002, 130, 1143-1151.

73. Zscheischler, J.; Seneviratne, S.I. Dependence of drivers affects risks associated with compound events. Sci. Adv. 2017, 3, e1700263. [CrossRef]

74. McVicar, T.R.; Roderick, M.L.; Donohue, R.J.; Van Niel, T.G. Less bluster ahead? Ecohydrological implications of global trends of terrestrial near-surface wind speeds. Ecohydrol. 2012, 5, 381-388. [CrossRef]

75. Roderick, M.L.; Rotstayn, L.D.; Farquhar, G.D.; Hobbins, M.T. On the attribution of changing pan evaporation. Geophys. Lett. 2007, 34, L17401-L17403. [CrossRef]

76. Wright, I.J.; Dong, N.; Maire, V.; Prentice, I.C.; Westoby, M.; Díaz, S.; Gallagher, R.V.; Jacobs, B.F.; Kooyman, R.; Law, E.A.; et al. Global climatic drivers of leaf size. Science 2017, 357, 917-921. [CrossRef]

77. Niinemets, U. Stomatal conductance alone does not explain the decline in foliar photosynthetic rates with increasing tree age and size in Picea abies and Pinus sylvestris. Tree Physiol. 2002, 22, 515-535. [CrossRef]

78. Zhang, X.W.; Wang, J.R.; Ji, M.F.; Milne, R.I.; Wang, M.H.; Liu, J.-Q.; Shi, S.; Yang, S.-L.; Zhao, C.-M. Higher Thermal Acclimation Potential of Respiration but Not Photosynthesis in Two Alpine Picea Taxa in Contrast to Two Lowland Congeners. PLoS One 2015, 10, e0123248. [CrossRef]

79. Taeger, S.; Sparks, T.H.; Menzel, A. Effects of temperature and drought manipulations on seedlings of Scots pine provenances. Plant Biol. 2015, 17, 361-372. [CrossRef]

80. Kurepin, L.V.; Stangl, Z.R.; Ivanov, A.G.; Bui, V.; Mema, M.; Hüner, N.P.; Öquist, G.; Way, D.; Hurry, V. Contrasting acclimation abilities of two dominant boreal conifers to elevated $\mathrm{CO} 2$ and temperature. Plant Cell 2018, 41, 1331-1345. [CrossRef]

(C) 2019 by the authors. Licensee MDPI, Basel, Switzerland. This article is an open access article distributed under the terms and conditions of the Creative Commons Attribution (CC BY) license (http://creativecommons.org/licenses/by/4.0/). 